\title{
Developmental Sequence of Chloride Cells in the Body Skin and Gills of Japanese Flounder (Paralichthys olivaceus) Larvae
}

\author{
Junya Hiroi ${ }^{1,2}$, Toyoji Kaneko², Tadahisa Seikai ${ }^{3}$ \\ and Masaru Tanaka ${ }^{1 *}$ \\ ${ }^{1}$ Division of Applied Biosciences, Graduate School of Agriculture, Kyoto University, \\ Kitashirakawa-Oiwakecho, Sakyo, Kyoto 606-8502, Japan \\ ${ }^{2}$ Ocean Research Institute, University of Tokyo, Minamidai, Nakano, Tokyo 164-8639, Japan \\ ${ }^{3}$ Fisheries Research Station, Kyoto University, Maizuru, Kyoto 625-0086, Japan
}

\begin{abstract}
The developmental sequence of chloride cells was examined in both the body skin and gills of Japanese flounder (Paralichthys olivaceus) larvae by whole-mount immunocytochemistry using an antiserum specific for $\mathrm{Na}^{+}, \mathrm{K}^{+}$-ATPase. In premetamorphic larvae at 0 and 4 days after hatching (days 0 and 4 ), immunoreactive chloride cells were distributed only in the yolk-sac membrane and body skin. Premetamorphic larvae at days 8-18 possessed both cutaneous and branchial chloride cells. Large chloride cells in the skin of premetamorphic larvae often formed multicellular complexes, suggestive of their ion-secreting function. Cutaneous chloride cells decreased in size and density at the beginning of metamorphosis (days 21 and 24), and disappeared at the metamorphic climax (days 28 and 33). In contrast, branchial chloride cells first appeared at day 8 , and increased during metamorphosis. These results indicate that the site for ion secretion in seawater may shift from cutaneous to branchial chloride cells during metamorphosis. The appearance of branchial chloride cells before the differentiation of gill lamellae suggests that the primary function of the gills during the early development is ion regulation rather than gas exchanges.
\end{abstract}

\section{INTRODUCTION}

Embryos and larvae of teleosts maintain the internal hydromineral balance, although important osmoregulatory organs in adults such as the gills, kidney and intestine are not fully developed (Alderdice, 1988). In juveniles and adults of marine teleosts, chloride cells in the gills are responsible for the secretion of excess $\mathrm{Na}^{+}$and $\mathrm{Cl}^{-}$in the body fluids (Zadunaisky, 1984). In embryos and larvae, chloride cells located in the epithelia covering the yolk and body have been suggested as ion-secreting sites in seawater (Shelbourne, 1957; Lasker and Threadgold, 1968; Hwang and Hirano, 1985; Alderdice, 1988; Hwang, 1989, 1990; Ayson et al., 1994; Kaneko et al., 1995; Shiraishi et al., 1997; Sasai et al., 1998a). Thus, these extrabranchial chloride cells as the major site for ion secretion seem to be taken over by branchial chloride cells as fish grow. However, the spatial shift of chloride cell distribution from the yolk-sac membrane and body skin to gills and their developmental sequence have not been demonstrated through the early development of teleosts.

Marine teleosts generally undergo physiological changes

\footnotetext{
* Corresponding author: Tel. +81-75-753-6220;

FAX. +81-75-753-6229.
}

as well as morphological and ecological changes during metamorphosis from larvae to juveniles. Japanese flounder (Paralichthys olivaceus) exhibit drastic metamorphosis from pelagic larvae to benthic juveniles, involving the migration of the right eye to the left side of the head. In the present study, to clarify the spatial shift of chloride cell distribution during metamorphosis, we examined the development of both cutaneous and branchial chloride cells in premetamorphic and metamorphic flounder larvae. To detect chloride cells, whole larvae were subjected to immunocytochemical staining with an antiserum specific for $\mathrm{Na}^{+}, \mathrm{K}^{+}$-ATPase, a key enzyme of ion transport in chloride cells.

\section{MATERIALS AND METHODS}

Fish

Naturally spawned eggs of Japanese flounder (Paralichthys olivaceus) were collected from a brood-stock tank in the Fisheries Research Station of Kyoto University. Larvae were reared in a polycarbonate tank ( $500 \mathrm{I})$ with running seawater. Water temperature was maintained at $18^{\circ} \mathrm{C}$, and the salinity ranged between 30.6 and 32.2 ppt. They were initially fed on rotifers (Brachionus plicatilis) cultivated with Nannochrolopsis sp. and $\omega$-Yeast (Kyowa Hakko Kogyo, Japan), and later on brine shrimp (Artemia spp.) nauplii enriched with Ester85 (Nippon Chemical Feed, Japan). Samples were taken at nine different developmental stages (Table 1). The larvae up to 18 days after 
Table 1. Relative frequency of chloride cells in the body skin and gills during the early development of Japanese flounder

\begin{tabular}{|c|c|c|c|c|}
\hline \multirow{2}{*}{$\begin{array}{l}\text { Days after } \\
\text { hatching }\end{array}$} & \multirow{2}{*}{$\begin{array}{l}\text { Developmental } \\
\text { stage }^{1}\end{array}$} & \multirow{2}{*}{$\begin{array}{l}\text { Body length } \\
\quad(\mathrm{mm})\end{array}$} & \multicolumn{2}{|c|}{ Chloride cell frequency ${ }^{2}$} \\
\hline & & & skin & gills \\
\hline \multicolumn{5}{|c|}{ premetamorphic larvae } \\
\hline 0 & & $2.5-2.6$ & + & - \\
\hline 4 & $A$ & $2.8-3.1$ & ++ & - \\
\hline 8 & B & $4.0-4.3$ & ++ & + \\
\hline 14 & $\mathrm{C}$ & $5.0-5.5$ & ++ & ++ \\
\hline 18 & $\mathrm{D}$ & $5.8-6.1$ & ++ & ++ \\
\hline \multicolumn{5}{|c|}{ metamorphic larvae } \\
\hline 21 & $E$ & $6.8-7.2$ & + & ++ \\
\hline 24 & $\mathrm{~F}$ & $7.3-7.5$ & \pm & ++ \\
\hline 28 & $\mathrm{G}$ & $8.0-8.9$ & - & ++ \\
\hline 33 & $\mathrm{H}$ & $9.5-10.2$ & - & ++ \\
\hline
\end{tabular}

${ }^{1}$ Developmental stages according to Minami (1982).

${ }^{2}-$, not detected; \pm , sparse; + , moderately dense; ++ , dense.

hatching (day 18) with symmetrical bodies were regarded as premetamorphic larvae, and those on and after day 21 with migrating right eyes as metamorphic larvae. Larvae were anesthetized with MS-222, fixed in $4 \%$ paraformaldehyde in $0.1 \mathrm{M}$ phosphate buffer $(\mathrm{pH} 7.4)$ for $20 \mathrm{hr}$ at $4{ }^{\circ} \mathrm{C}$, and preserved in $70 \%$ ethanol.

\section{Whole-mount immunocytochemistry}

As a specific probe for chloride cells, we used an antiserum specific for $\mathrm{Na}^{+}, \mathrm{K}^{+}$-ATPase, which is localized in the membrane of the tubular systems distributed extensively over the cytoplasm of chloride cells (Karnaky et al., 1976; Hootman and Philpott, 1979). The antiserum was raised in a rabbit against a synthetic peptide corresponding to part of the highly conserved region of the $\mathrm{Na}^{+}, \mathrm{K}^{+}$-ATPase $\alpha$-subunit (Ura et al., 1996). It has been well documented that the anti- $\mathrm{Na}^{+}, \mathrm{K}^{+}$-ATPase specifically detects both cutaneous and branchial chloride cells in several teleosts (Ura et al., 1996; Uchida et al., 1996; Shiraishi et al., 1997; Sasai et al., 1998a, b).

Whole-mount immunocytochemistry based on the avidin-biotinperoxidase complex (ABC) method (Hsu et al., 1981) was carried out following the method of Ohtani et al. (1989) using commercial reagents (Vectastain Elite ABC kit, Vector Laboratories, USA). The right operculum of larvae after day 4 was removed prior to the immunostaining in order to enhance penetration of solutions to the gills. After treatment with $0.1 \%$ sodium cyanoborohydride in $0.01 \mathrm{M}$ phosphate-buffered saline (PBS, pH 7.2) for $1 \mathrm{hr}$, the samples were incubated sequentially with: 1) rabbit anti- $\mathrm{Na}^{+}, \mathrm{K}^{+}$-ATPase diluted 1:500 for $20 \mathrm{hr}$ at $4^{\circ} \mathrm{C}, 2$ ) biotinylated goat anti-rabbit $\lg \mathrm{G}$ for $20 \mathrm{hr}$ at $4^{\circ} \mathrm{C}, 3$ ) $\mathrm{ABC}$ reagent for $20 \mathrm{hr}$ at $4^{\circ} \mathrm{C}$, and 4) $0.03 \% 4-\mathrm{Cl}-1$-naphthol in $0.05 \mathrm{M}$ Tris- $\mathrm{HCl}$ buffer $(\mathrm{pH} 7.6)$ containing $0.003 \%$ hydrogen peroxide for 20 min. The antisera and $A B C$ reagent were diluted with PBS containing $0.05 \%$ Triton $\mathrm{X}-100,10 \%$ normal goat serum, $0.1 \%$ bovine serum albumin and $0.01 \%$ sodium azide. The whole sample and separated gill arches were mounted on a slide with glycerin.

The image of the body surface on the left side was digitized with a CCD video camera (Victor, Japan) and an image processor (ARGUS 20, Hamamatsu photonics, Japan), and the size and density of immunopositive chloride cells in the body skin were measured on an Apple Macintosh computer using the public domain NIH Image program (available on the Internet at http://rsb.info.nih.gov/nih-image/). The quantitative analysis was made on cutaneous chloride cells only in the yolk-sac membrane and the skin of trunk and tail, in which chloride cells were uniformly distributed during early developmental stages. The head region, finfold of premetamorphic larvae and fins of metamorphic larvae were excluded from the measurement, because the sparseness of chloride cells in these regions was considered in- appropriate for density measurement. The quantitative analysis of branchial chloride cells was not carry out, since it was difficult to measure the precise cell density and size in the complicated, three-dimensional structures of the gills.

\section{RESULTS}

\section{Chloride cells in the skin}

In newly-hatched flounder larvae (day 0), weakly-immunopositive but large chloride cells were detected in the epithelia covering both the yolk and body (Fig. 1A, B). In premetamorphic larvae at days 4-18, a large number of immunopositive chloride cells were distributed in the body skin (Fig. 1C-F). Chloride cells in the skin of newly-hatched and premetamorphic larvae were characterized by the formation of cell clusters: several chloride cells congregated to form a multicellular complex as indicated by the presence of more than one immunonegative nuclei (Fig. 1B, D, F). Especially, large chloride cell complexes were observed in the abdominal region. In metamorphic larvae at day 21 just starting the right-eye migration, both size and density of chloride cells decreased (Fig. 1G, H). In contrast with premetamorphic larvae, these chloride cells were present individually and did not form multicellular complexes. No chloride cells were detected in the body skin of metamorphic-climax larvae at days 28 and 33. However, small immunopositive cells not forming cellular complexes were found in the pectoral, dorsal and anal fins of metamorphic larvae at days 21-33, although few chloride cells were detectable in the pectoral fin and finfold of premetamorphic larvae at days 0-18. Figure 2 shows developmental changes in size-frequency distributions of chloride cells and chloride cell complexes in the yolk-sac membrane and body skin. During the early development, the mean size of chloride cells decreased concomitant with the disappearance of chloride cell complexes. The density of chloride cells was decreased drastically at the beginning of metamorphosis (days 21 and 24), and the cells disappeared at the metamorphic climax at days 28 and 33 (data not shown). 


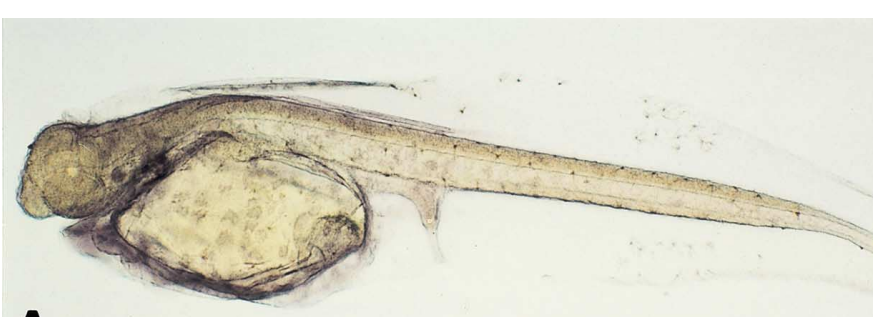

A

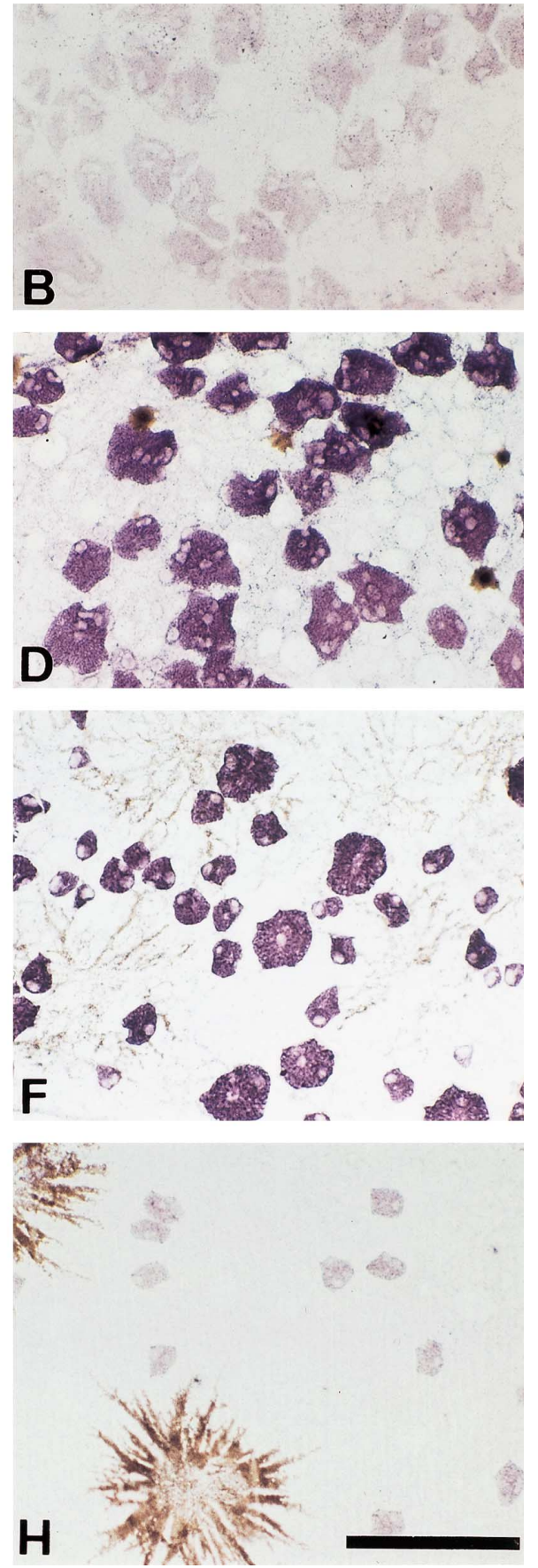

Fig. 1. Cutaneous chloride cells of flounder larvae at day 0 (A, B), day 8 (C, D), day $18(\mathbf{E}, \mathbf{F})$ and day 24 (G, H), detected by whole-mount immunocytochemistry using an antiserum specific for $\mathrm{Na}^{+}, \mathrm{K}^{+}$-ATPase. (B, D, F, H) Magnified views of separated yolk-sac membrane or body skin in the abdominal region. Bars: (A, C, E, G) $500 \mu \mathrm{m}$; (B, D, F, H) $100 \mu \mathrm{m}$.

\section{Chloride cells in the gills}

The gills were not distinguishable in the whole-mount preparation of newly-hatched larvae at day 0 . Four pairs of gill arches were recognizable in larvae at day 4 , although the gill filament and lamella were not yet differentiated. Chloride cells were not yet detected in the gill arches at this early developmental stage. In premetamorphic larvae at day 8 , gill filaments sprouted from the gill arches but the lamella was not differentiated. Immunoreactive chloride cells were ob- served in the filament epithelia of all the four pairs of gills (Fig. $3 \mathrm{~A})$. In premetamorphic larvae at day 18 , the filaments were further developed and the lamellae were extended from the filaments. Chloride cells were extensively distributed in the filaments, but were absent in the lamellae (Fig. 3B). In metamorphic larvae at day 24, when the filaments and lamellae were extended further, chloride cells were overspread in the filaments, whereas no chloride cell was observed in the lamellae (Fig. 3C). 


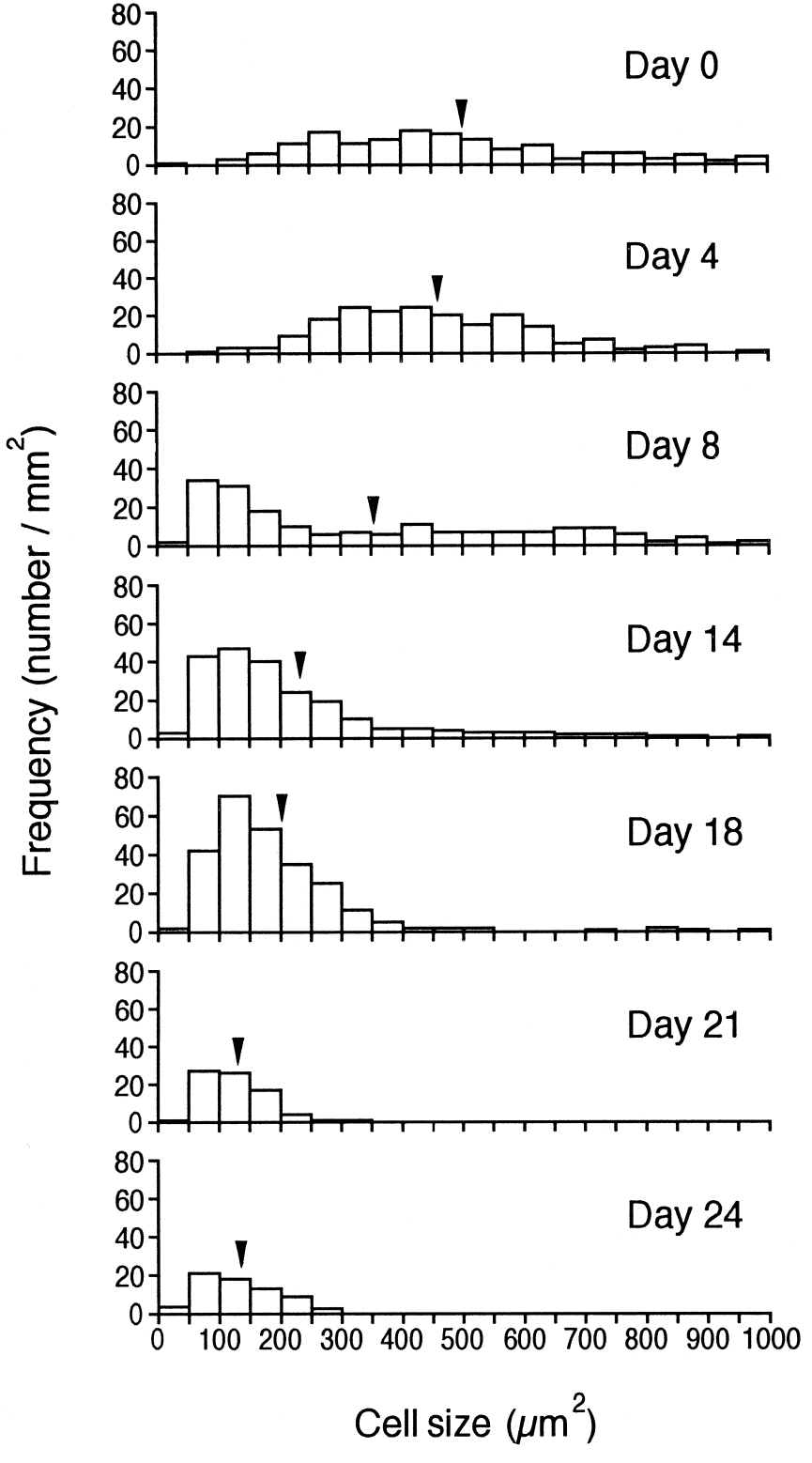

Fig. 2. Developmental changes in size-frequency distributions of chloride cells in the yolk-sac membrane and body skin of flounder larvae. Data obtained from 4 individuals were combined at each day. Arrows indicate the mean values. No chloride cell is detectable in the body skin at days 28 and 33 .

\section{DISCUSSION}

In the present study, the developmental sequence of both cutaneous and branchial chloride cells was clarified in the early life stages of Japanese flounder by the whole-mount immunocytochemistry. As summarized in Table 1, the chloride cell distribution shifts from the body skin to the gills during the early development. Such a spatial shift of chloride cell distribution is closely associated with metamorphosis.

Larvae at days 0 and 4 possessed only cutaneous chloride cells, which seem to be the only functional site for ion secretion at these early developmental stages. In premetamorphic larvae at days 8-18, a large number of chloride cells
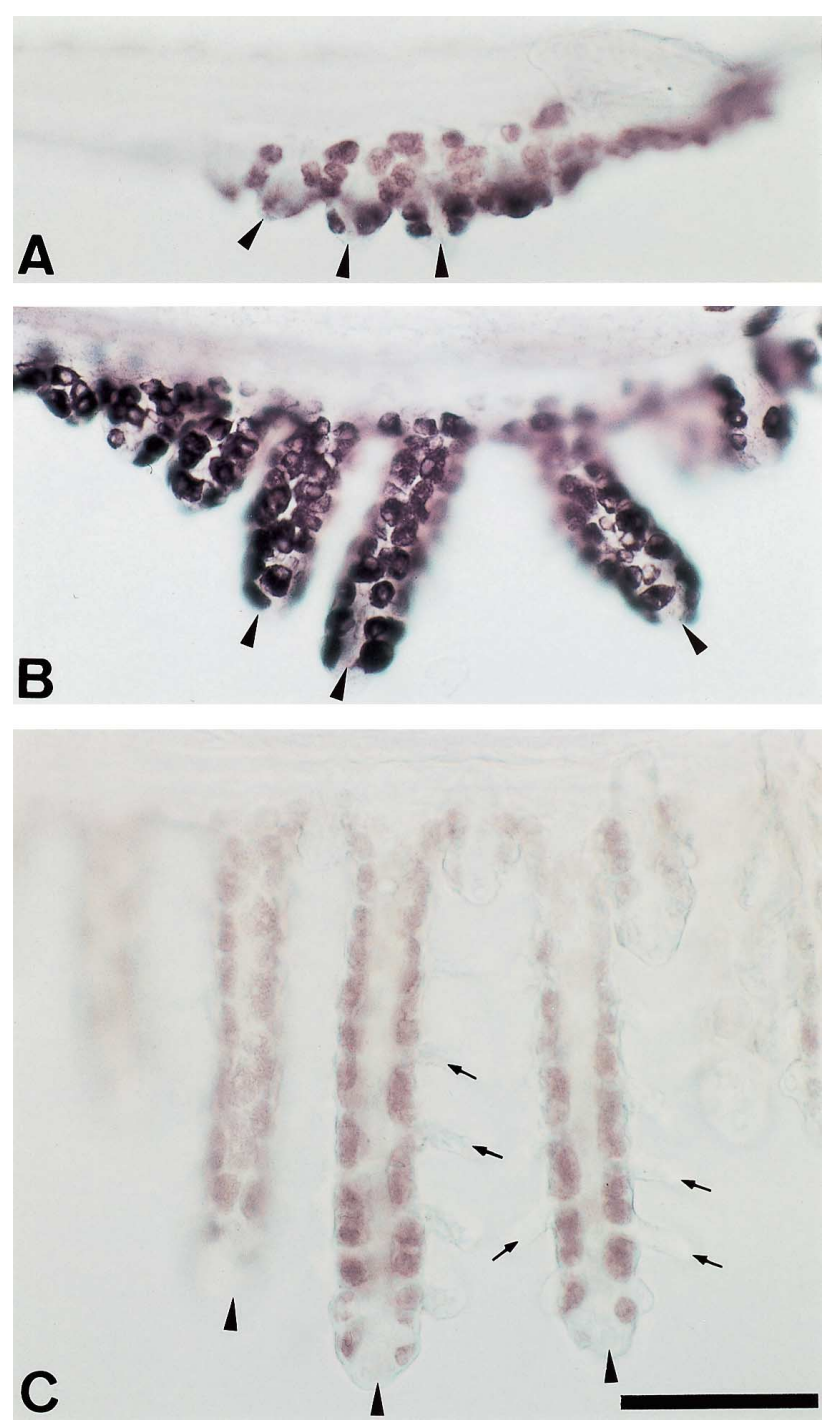

Fig. 3. Branchial chloride cells in the first gill arch of the right side of flounder larvae at day $8(\mathbf{A})$, day $18(\mathbf{B})$ and day $24(\mathbf{C})$, detected by whole-mount immunocytochemistry using an antiserum specific for $\mathrm{Na}^{+}, \mathrm{K}^{+}$-ATPase. The gill lamellae are already differentiated at day 18 (B), although they are not visible because of being out of focus. Arrowheads and arrows indicate gill filaments and lamellae, respectively. Bar: $100 \mu \mathrm{m}$.

were observed in both the body skin and gills. Although the mean size of cutaneous chloride cells decreased gradually during the development, the cell density increased and reached the highest value at day 18, just before the beginning of metamorphosis. We did not carry out a quantitative analysis of branchial chloride cells, since it was difficult to measure the precise cell density and size in the complicated, three-dimensional structures of the gills. However, the branchial chloride cell number certainly increased during the development. These findings suggest that both cutaneous and branchial chloride cells function cooperatively as the site for ion secretion at these premetamorphic stages. Later on, cutaneous chloride cells disappeared and branchial chloride cell number increased 
further during metamorphosis. These observations clearly indicate that the site for ion secretion shifts from cutaneous to branchial chloride cells during flounder metamorphosis.

During the metamorphosis of Japanese flounder, a series of physiological changes occurs: larval types of the digestive system, muscles and erythrocytes change into adult types (Tanaka, 1973; Yamano et al., 1991; Miwa and Inui, 1991; Miwa et al., 1992). The shift from cutaneous to branchial chloride cells would be categorized as one of such physiological changes during metamorphosis. Besides Japanese flounder, many other marine teleosts also exhibit metamorphosis to varying degrees. The shift from cutaneous to branchial chloride cells observed in Japanese flounder could be expected to occur during metamorphosis in those teleosts.

A large proportion of cutaneous chloride cells in premetamorphic flounder larvae formed multicellular complexes. Similar chloride cell complexes have been reported in the yolksac membrane and body skin of tilapia (Oreochromis mossambicus) and Japanese eel (Anguilla japonica) embryos and larvae reared in seawater (Shiraishi et al., 1997; Sasai et al., 1998a). Shiraishi et al. (1997) have proved that a chloride cell complex in the yolk-sac membrane of seawater-adapted tilapia larvae consists of a main chloride cell and adjacent accessory cells, which interdigitate with each other to form multiple junctions. The complex is considered to be advantageous to $\mathrm{Na}^{+}$secretion, since $\mathrm{Na}^{+}$secretion may occur down its electrochemical gradient via a paracellular pathway in the complex (Marshall, 1995; McCormick, 1995). Therefore, the occurrence of chloride cell complexes in the body skin of premetamorphic flounder larvae would provide morphological evidence that those cells function as ion-secreting sites in seawater.

It should be noted that branchial chloride cells first appeared on the gill filaments before the differentiation of lamellae at day 8 . Since the lamellae are largely involved in gas exchanges by enlarging the branchial surface area, the primary function of the gills during the early development seems to be ion regulation rather than gas exchanges.

In metamorphic larvae, although the gills were equipped with filaments and lamellae, chloride cells were distributed only in the filaments but not in the lamellae. Two distinct types of chloride cells have been reported in the gill filaments and lamellae of chum salmon (Oncorhynchus keta) fry and adults and Japanese eel adults (Uchida et al., 1996, 1997; Sasai et al., $1998 b)$. In the gills of these species adapted to fresh water, chloride cells were found in both filaments and lamellae. After transfer to seawater, the number of lamellar chloride cells decreased and filament chloride cells were activated. These morphological observations suggest that filament and lamellar chloride cells are involved in seawater and freshwater adaptation, respectively. Therefore, filament chloride cells of flounder larvae may be important in seawater adaptation, most probably acting as the site for salt secretion in hyperosmotic environments. In nature, flounder larvae migrate from offshore areas to estuaries during metamorphosis, when the low-salinity tolerance develops to some extent (Hiroi et al., 1997).
Observations on branchial chloride cell alteration during the adaptation to hypoosmotic environments would be of considerable interest to explore diverse functions of chloride cells in iono- and osmoregulation.

\section{ACKNOWLEDGMENTS}

We are grateful to Professor Kohei Yamauchi, Hokkaido University, and Professor Kiyoshi Soyano, Nagasaki University, for providing the anti- $\mathrm{Na}^{+}, \mathrm{K}^{+}$-ATPase serum. This study was supported in part by Grants-in-Aid for Scientific Research from the Ministry of Education, Science, Sports and Culture, and the Fisheries Agency, Japan. J.H. was supported by Research Fellowships of Japan Society for Promotion of Science for Young Scientists.

\section{REFERENCES}

Alderdice DF (1988) Osmotic and ionic regulation in teleost eggs and larvae. In "Fish Physiology Vol 11A" Ed by WS Hoar, DJ Randall, Academic Press, San Diego, pp 163-251

Ayson FG, Kaneko T, Hasegawa S, Hirano T (1994) Development of mitochondrion-rich cells in the yolk-sac membrane of embryos and larvae of tilapia, Oreochromis mossambicus, in fresh water and seawater. J Exp Zool 270: 129-135

Hiroi J, Sakakura Y, Tagawa M, Seikai T, Tanaka M (1997) Developmental changes in low-salinity tolerance and responses of prolactin, cortisol and thyroid hormones to low-salinity environment in larvae and juveniles of Japanese flounder, Paralichthys olivaceus. Zool Sci 14: 987-992

Hootman SR, Philpott CW (1979) Ultracytochemical localization of $\mathrm{Na}^{+}, \mathrm{K}^{+}$-activated ATPase in chloride cells from gills of a euryhaline teleost. Anat Rec 193: 99-130

Hsu SM, Raine L, Fanger H (1981) Use of avidin-biotin-peroxidase complex $(A B C)$ in immunoperoxidase techniques: a comparison between $A B C$ and unlabeled antibody (PAP) procedures. J Histochem Cytochem 29: 577-580

Hwang PP (1989) Distribution of chloride cells in teleost larvae. J Morphol 200: 1-8

Hwang PP (1990) Salinity effects on development of chloride cells in the larvae of ayu (Plecoglossus altivelis). Mar Biol 107: 1-7

Hwang PP, Hirano R (1985) Effects of environmental salinity on intercellular organization and junctional structure of chloride cells in early stages of teleost development. J Exp Zool 236: 115-126

Kaneko T, Hasegawa S, Takagi Y, Tagawa M, Hirano T (1995) Hypoosmoregulatory ability of eyed-stage embryos of chum salmon. Mar Biol 122: 165-170

Karnaky KJJ, Kinter LB, Kinter WB, Stirling CE (1976) Teleost chloride cell. II. Autoradiographic localization of gill $\mathrm{Na}$, K-ATPase in Killifish Fundulus heteroclitus adapted to low and high salinity environments. J Cell Biol 70: 157-177

Lasker R, Threadgold LT (1968) "Chloride cells" in the skin of the larval sardine. Exp Cell Res 52: 582-590

Marshall WS (1995) Transport processes in isolated teleost epithelia: opercular epithelium and urinary bladder. In "Fish Physiology Vol 14" Ed by CM Wood, TJ Shuttleworth, Academic Press, San Diego, pp 1-23

McCormick SD (1995) Hormonal control of gill $\mathrm{Na}^{+}, \mathrm{K}^{+}$-ATPase and chloride cell function. In "Fish Physiology Vol 14" Ed by CM Wood, TJ Shuttleworth, Academic Press, San Diego, pp 285-315

Minami T (1982) The early life history of a flounder Paralichthys olivaceus. Bull Japan Soc Sci Fish 48: 1581-1588

Miwa S, Inui Y (1991) Thyroid hormone stimulates the shift of erythrocyte populations during metamorphosis of the flounder. J Exp Zool 259: 222-228

Miwa S, Yamano K, Inui Y (1992) Thyroid hormone stimulates gastric 
development in flounder larvae during metamorphosis. J Exp Zool 261: 424-430

Ohtani R, Kaneko T, Kline LW, Labedz T, Tang Y, Pang PKT (1989) Localization of calcitonin gene-related peptide in the small intestine of various vertebrate species. Cell Tissue Res 258: 35-42

Sasai S, Kaneko T, Tsukamoto K (1998a) Extrabranchial chloride cells in early life stages of Japanese eel, Anguilla japonica. Ichthyol Res 45: 95-98

Sasai S, Kaneko T, Hasegawa S, Tsukamoto K (1998b) Morphological alteration in two types of gill chloride cells in Japanese eel (Anguilla japonica) during catadromous migration. Can J Zool (in press)

Shelbourne JE (1957) Site of chloride regulation in marine fish larvae. Nature 180: 920-922

Shiraishi K, Kaneko T, Hasegawa S, Hirano T (1997) Development of multicellular complexes of chloride cells in the yolk-sac membrane of tilapia (Oreochromis mossambicus) embryos and larvae in seawater. Cell Tissue Res 288: $583-590$

Tanaka M (1973) Studies on the structure and function of the digestive system of teleost larvae. Kyoto University Ph D Thesis

Uchida K, Kaneko T, Yamauchi K, Hirano T (1996) Morphometrical analysis of chloride cell activity in the gill filaments and lamellae and changes in $\mathrm{Na}^{+}, \mathrm{K}^{+}$-ATPase activity during seawater adaptation in chum salmon fry. J Exp Zool 276: 193-200
Uchida K, Kaneko T, Yamaguchi A, Ogasawara T, Hirano T (1997) Reduced hypoosmoregulatory ability and alteration in gill chloride cell distribution in mature chum salmon (Oncorhynchus keta) migrating upstream for spawning. Mar Biol 129: 247-253

Ura K, Soyano K, Omoto N, Adachi S, Yamauchi K (1996) Localization of $\mathrm{Na}^{+}, \mathrm{K}^{+}$-ATPase in tissues of rabbit and teleosts using an antiserum directed against a partial sequence of the $\alpha$-subunit. Zool Sci 13: 219-227

Yamano K, Miwa S, Inui Y (1991) Thyroid hormone regulates developmental changes in muscle during flounder metamorphosis. Gen Comp Endocrinol 81: 464-472

Zadunaisky JA (1984) The chloride cell: The active transport of chloride and the paracellular pathways. In "Fish Physiology Vol 10B" Ed by WS Hoar, DJ Randall, Academic Press, Orlando, pp 130176

(Received April 21, 1998 / Accepted May 14, 1998) 